\title{
Analisis Berpikir Literasi Matematika Berdasarkan Kecerdasan Logika Matematika Siswa SMP
}

\section{Maria Ulfah ${ }^{1}$, Hamidah Suryani Lukman, Novi Andri Nurcahyono \\ ${ }^{1}$ Universitas Muhammadiyah Sukabumi \\ 1ulfah9505@gmail.com}

\begin{tabular}{l}
\hline \hline Article Info \\
\hline Article history: \\
Received June $20^{\text {th }}, 2020$ \\
Revised July $16^{\text {th }}, 2020$ \\
Accepted Nov $16^{\text {th }}, 2020$ \\
\hline
\end{tabular}

Keywords:

Analysis;

Literation;

Mathematics Logic

Intelligence

Based on preliminary analysis, students' mathematics literacy thinking skills are relatively low. One of the factors that affected it is mathematics logic intelligence. This research aims to describe the students mathematics literacy thinking skills based on high, medium and low intelligence mathematics logic. This research is a inquiry study with a qualitative approach and descriptive qualitative research design and data collection techniques in the form of questionnaries and tests. The subjects in this study were three students of 8th grades of SMP Negeri 1 Sukabumi city, the type of subject taking in this study using the purposive sampling. Based on the results of the study, the students that possesses a high mathematics logic intelligence reach the three components of mathematics literacy thinking that formulate mathematical situations, applying mathematics concepts, facts, procedures, and mathematics reasoning, and interpret, applying and evaluate the results. Students who acquire mathematics logic intelligence categories are fulfilling the two components of mathematics literacy thinking namely formulating mathematical situations and applying mathematics concepts, facts, procedures and mathematics reasoning. Meanwhile, the students that possesses a low mathematics logic intelligence reach one indicator of one component of mathematics literacy thinking ability.

\section{Kata Kunci:}

Analisis;

Literasi;

Kecerdasan Logika Matematika

\section{Abstrak}

Berdasarkan analisis pendahuluan, kemampuan berpikir literasi matematika siswa masih terbilang rendah. Salah satu faktor yang mempengaruhi hal tersebut adalah kecerdasan logika matematika. Penelitian ini bertujuan untuk mendeskripsikan kemampuan berpikir literasi matematika siswa berdasarkan kecerdasan logika 
matematika dengan kategori tinggi, sedang dan rendah. Jenis penelitian ini adalah studi kasus dengan pendekatan kualitatif dan desain penelitian deskriptif kualitatif serta teknik pengumpulan data berupa pemberian angket dan tes. Subjek pada penelitian ini yaitu 3 orang siswa Kelas VIII SMP Negeri 1 Kota Sukabumi, pengambilan subjek pada penelitian ini menggunakan purposive sampling. Berdasarkan hasil penelitian, bahwa siswa yang memiliki kecerdasan logika matematika kategori tinggi memenuhi ketiga komponen berpikir literasi matematika yaitu merumuskan situasi secara matematis, menerapkan konsep matematika, fakta, prosedur dan penalaran matematika, serta menafsirkan, menerapkan dan mengevaluasi hasil. Siswa yang memiliki kecerdasan logika matematika kategori sedang memenuhi dua komponen berpikir literasi matematika yaitu merumuskan situasi secara matematis dan menerapkan konsep matematika, fakta, prosedur dan penalaran matematika. Siswa yang memiliki kecerdasan logika matematika kategori rendah memenuhi satu indikator dari satu komponen kemampuan berpikir literasi matematika yaitu menemukan pola, mengolah data dan informasi.

\section{PENDAHULUAN}

Kualitas pendidikan sering digunakan sebagai acuan perkembangan suatu negara (Kurniawati dan Kurniasari, 2019: 441). Pengembangan dalam pendidikan diharapkan dapat membentuk manusia yang mampu mengikuti dan melibatkan diri dalam proses perkembangan ilmu pengetahuan dan teknologi terutama matematika (Holis dkk, 2016: 142). Matematika dapat diartikan sebagai materi mata pelajaran sekolah yang dirancang sesuai dengan kemampuan dan kebutuhan siswa agar dapat mengembangkan ketajaman penalaran, berfikir logis, analitis, sistematis, kritis, kreatif dan inovatif (Salafudin, 2015: 226). Matematika juga dapat dimanfaatkan untuk mengaitkan gagasan matematika dengan konteks kehidupan modern melalui kreativitasnya dalam memilih bagaimana menyelesaikan permasalahan yang ada di sekitar kehidupannya (Rosalina dan Ekawati, 2017: 54). 
Menyelesaikan permasalahan tersebut diperlukan kemampuan matematika yang tidak hanya sekedar berhitung atau dioperasikannya saja tetapi diperlukan literasi matematika (Fadillah dan Ni'mah, 2019: 127). Sehingga mempunyai kemampuan berpikir literasi matematika sangat dibutuhkan untuk menyelesaikan permasalahan-permasalahan yang dihadapi siswa dalam kehidupannya. Menurut Indrawati dan Wardono (2019) literasi matematika yaitu kemampuan yang dimiliki individu untuk merumuskan, menerapkan serta menafsirkan matematika dalam berbagai konteks yang melibatkan penalaran matematis dan penggunaan konsep untuk mendeskripsikan, dan memprediksi fenomena serta mengaitkan dengan kehidupan sehari-hari. Selain itu, menurut Mhakure dan Mokoena (2011: 310) "Mathematical literacy is one of the keys to coping in a changing and technological society" yang artinya literasi matematika adalah salah satu kunci untuk menghadapi perubahan masyarakat teknologi.

Mempunyai kemampuan berpikir literasi matematika merupakan kemampuan yang memang penting dimiliki siswa. Tetapi literasi matematika siswa Indonesia masih terbilang belum memuaskan di mata internasional. Hal tersebut ditunjukkan oleh fakta di lapangan, terlihat dari hasil kajian yang dilakukan oleh Programme for International Student Assessment (PISA) yang diselenggarakan oleh Organization for Economic Cooperation and Development (OECD). Dimana kemampuan matematika siswa Indonesia masih belum memuaskan, yaitu berada pada peringkat 72 dari 78 negara, hal tersebut berdasarkan studi PISA pada tahun 2018 (OECD, 2019). Dimana objek yang dikaji PISA dalam matematika tidak hanya sekedar prestasi belajar, tetapi kajian dalam bidang matematika pun menjadi komponen kajian PISA yaitu kemampuan yang diistilahkan dengan literasi matematika (Syahwid dan Putrawangsa, 2017: 223).

Hasil tersebut diperkuat dengan beberapa temuan di lapangan yang menunjukkan rendahnya kemampuan berpikir literasi matematika siswa. Berdasarkan analisis pendahuluan, kemampuan berpikir literasi matematika siswa SMP Kelas VIII H pada SMPN 1 Sukabumi masih terbilang rendah. Hal tersebut dapat dilihat pada gambar 1 di bawah ini 
yang merupakan jawaban siswa terhadap tes berpikir literasi matematika, dimana pada jawaban tersebut terlihat siswa belum memenuhi indikator berpikir literasi matematika.

yang pasti eskul musik lebih banyak to onggota daripada eskul drama
antaro 19.500 - 19.8nn?

\section{Gambar 1 Jawaban siswa}

Terdapat beberapa faktor yang berpengaruh terhadap kemampuan literasi matematika, salah satunya yaitu kecerdasan yang dimiliki siswa (Elisa, 2017). Gardner membagi kecerdasan manusia ke dalam delapan kecerdasan yang salah satunya yaitu kecerdasan logika matematika. Kecerdasan logika matematika merupakan kemampuan seseorang dalam menggunakan angka-angka untuk menghitung dan mendeskripsikan sesuatu, menggunakan konsep matematika, menerapkan matematika dalam kehidupan sehari-hari (Fathani, 2016). Sehingga kecerdasan logika matematika merupakan kemampuan yang dimiliki seseorang dalam menggunakan konsep matematika untuk memecahkan masalah dalam berbagai konteks. Kecerdasan logika matematika sangat dibutuhkan dalam menyelesaikan tes berpikir literasi matematika. Karena siswa dengan kecerdasan logika matematika akan memiliki kemampuan untuk memahami masalah, melakukan perhitungan serta kemampuan menalar dan berabstraksi untuk memecahkan masalah (Kurniawati dan Kurniasari, 2019).

Menurut penelitian yang telah dilakukan oleh Elisa (2017) mengenai kemampuan literasi matematika siswa dengan kecerdasan logis matematis, bahwa siswa mampu mengidentifikasi variabel dan aspek matematika, menggunakan bahasa yang kurang komunikatif dan informatif ketika menuliskan masalah sesuai dengan situasi yang diketahui pada soal, mampu menentukan ide awal dan mengidentifikasi kendala dan asumsi, mengetahui struktur matematika (sifat yang beraturan, hubungan, dan pola) namun tidak menuliskannya pada lembar jawaban tes kemampuan literasi matematika. Siswa mampu menerapkan strategi untuk menemukan solusi serta menerapkan definisi matematika, 
kaidah dan algoritma selama proses menemukan solusi, namun kurang maksimal dalam memanipulasi bilangan dan data, mampu menerapkan strategi untuk memecahkan masalah serta menerapkan definisi matematika, kaidah dan algoritma dalam proses memecahkan masalah. Selanjutnya menurut penelitian dari Aini dkk (2018) mengenai berpikir literasi matematika siswa dengan kecerdasan logis matematis, dimana siswa dapat memenuhi semua indikator pada komponen proses berpikir literasi tetapi terdapat beberapa loncatan langkah dalam menulis jawaban serta dalam menyelesaikan masalah mampu menggunakan operasi matematika dengan baik.

Terdapat beberapa persamaaan antara hasil penelitian di atas dengan penelitian ini, yaitu penelitian tentang kemampuan literasi matematika dan berpikir literasi matematika siswa dengan kecerdasan logis matematis. Adapun perbedaannya, pada penelitian ini akan diteliti mengenai bagaimana berpikir literasi matematika siswa berdasarkan kecerdasan logika matematika kategori tinggi, sedang dan rendah. Hal tersebut ditujukan agar mengetahui ketercapaian indikator siswa dengan kecerdasan logika matematika setiap kategori pada komponen berpikir literasi matematika. Berdasarkan uraian-uraian tersebut, tujuan penelitian ini yaitu mengkaji dan mengidentifikasi berpikir literasi matematika siswa pada SMP Negeri 1 Kota Sukabumi berdasarkan kecerdasan logika matematika.

\section{METODE PENELITIAN}

Metode penelitian yang digunakan yaitu studi kasus dengan pendekatan kualitatif, alasan penggunaan metode penelitian ini karena studi kasus merupakan metode penelitian yang berusaha meneliti dan menelaah fenomena yang muncul serta selanjutnya diuraikan ke dalam laporan penelitian. Adapun desain penelitian yang digunakan yaitu deskriptif kualitatif. Penelitian dilaksanakan dari tanggal 6 Februari 2020 sampai 20 Juni 2020 pada kelas VIII SMP Negeri 1 Kota Sukabumi, dimana subjek penelitian sebanyak 3 orang. Pengumpulan data dilakukan dalam dua tahap, dimana pada tahap pertama semua siswa diberikan angket kecerdasan logika matematika. Angket kecerdasan logika 
matematika yang digunakan pada penelitian ini merupakan angket yang diadaptasi dari Buku Armstrong dengan judul Kecerdasan Multipel di dalam Kelas. Jawaban siswa terhadap angket kecerdasan logika matematika digunakan untuk memilih subjek penelitian, dimana yang menjadi subjek penelitian yaitu siswa yang memiliki kecerdasan logika matematika dengan kategori tinggi, sedang dan rendah. Kategori tersebut didapatkan dari jawaban siswa terhadap angket kecerdasan logika matematika. Angket terdiri dari 10 pernyataan, pada setiap pernyataan diberi 4 pilihan diantaranya sangat setuju (skor 4), setuju (skor 3), tidak setuju (skor 2) dan sangat tidak setuju (skor 1). Skor maksimal dari angket adalah 40 dan skor terendah adalah 10. Jumlah skor yang didapatkan dari angket, kemudian diklasifikasikan dengan menggunakan skala Likert. Berikut adalah perhitungan skala Likert

$$
\text { Interval Nilai }=\frac{\text { Range }}{\text { Banyaknya kaegor } i}=\frac{30}{3}=10
$$

Keterangan:

Range $\quad$ Skor tertinggi - skor terendah $=40-10=30$

Banyaknya kategori : 3 (tinggi, sedang dan rendah)

Berdasarkan perhitungan di atas, dapat dihasilkan klasifikasi seperti pada Tabel 1, yaitu sebagai berikut.

Tabel 1 Tabel Klasifikasi Kategori Kecerdasan Logika Matematika

\begin{tabular}{cc}
\hline Interval Skor & Kategori \\
\hline $10-20$ & Rendah \\
$20-30$ & Sedang \\
$30-40$ & Tinggi \\
\hline
\end{tabular}

Berdasarkan angket kecerdasan logika matematika, dipilih 3 siswa yang memiliki kecerdasan logika matematika kategori tinggi, sedang dan rendah. Pengambilan subjek tersebut dengan menggunakan purposive sampling, karena purposive sampling merupakan teknik pengambilan subjek dengan pertimbangan tertentu, dimana subjek penelitian merupakan siswa yang memiliki kecerdasan logika matematika kategori tinggi, sedang dan rendah. Pengumpulan data tahap kedua yaitu pemberian tes berpikir literasi matematika dengan materi Sistem Persamaan Linear Dua Variabel (SPLDV). Soal tes berpikir literasi matematika diadaptasi dari buku Kementerian Pendidikan dan 
Kebudayaan Republik Indonesia Mata Pelajaran Matematika Kelas VIII Semester 1 Edisi Revisi 2017. Jawaban siswa terhadap tes literasi matematika digunakan untuk mengetahui bagaimana berpikir literasi matematika siswa. Analisis berpikir literasi matematika ini berdasarkan indikator berpikir literasi matematika (Tabel 2). Adapun keabsahan data yang digunakan pada penelitian ini yaitu triangulasi teknik. Serta analisis data dilakukan dalam dua tahap yaitu analisis data sebelum di lapangan yaitu studi pendahuluan, selanjutnya analisis data setelah di lapangan yaitu mereduksi data, menyajikan data terakhir menarik kesimpulan.

\section{HASIL PENELITIAN DAN PEMBAHASAN}

Berikut adalah indikator berpikir literasi matematika menurut Aini dkk (2018).

\section{Tabel 2 Indikator Berpikir Literasi Matematika}

\begin{tabular}{|c|c|}
\hline $\begin{array}{c}\text { Komponen Proses Berpikir } \\
\text { Literasi Matematika } \\
\end{array}$ & Indikator Berpikir Literasi Matematika \\
\hline \multirow[t]{4}{*}{$\begin{array}{l}\text { Merumuskan situasi } \text { secara } \\
\text { matematis }\end{array}$} & $\begin{array}{l}\text { 1. Mengidentifikasi konsep SPLDV dalam } \\
\text { permasalahan }\end{array}$ \\
\hline & $\begin{array}{l}\text { 2. Menggambarkan situasi matematis } \\
\text { dengan menggunakan simbol yang } \\
\text { terdapat pada SPLDV }\end{array}$ \\
\hline & $\begin{array}{l}\text { 3. Menemukan hubungan antar variabel } \\
\text { berdasakan fakta }\end{array}$ \\
\hline & $\begin{array}{l}\text { 4. Membuat model matematika } \\
\text { berdasarkan permasalahan }\end{array}$ \\
\hline \multirow{3}{*}{$\begin{array}{l}\text { Menerapkan } r \text { konsep } \\
\text { matematika, fakta, prosedur } \\
\text { dan penalaran matematika }\end{array}$} & $\begin{array}{l}\text { 1. Merancang strategi dalam menemukan } \\
\text { pola SPLDV }\end{array}$ \\
\hline & $\begin{array}{l}\text { 2. Menerapkan fakta, operasi dan struktur } \\
\text { saat menemukan solusi }\end{array}$ \\
\hline & $\begin{array}{l}\text { 3. Menemukan pola, mengolah data dan } \\
\text { informasi }\end{array}$ \\
\hline \multirow[t]{3}{*}{$\begin{array}{l}\text { Menafsirkan, menerapkan dan } \\
\text { mengevaluasi } \\
\text { matematika }\end{array}$} & $\begin{array}{l}\text { 1. Menginterpretasikan kembali hasil } \\
\text { pemecahan masalah ke dalam konteks } \\
\text { nyata }\end{array}$ \\
\hline & $\begin{array}{l}\text { Menyimpulkan dari perma } \\
\text { yang diberikan }\end{array}$ \\
\hline & Mengevaluasi hasil matematika \\
\hline
\end{tabular}


Indikator berpikir literasi digunakan untuk mengetahui berpikir literasi matematika siswa, berdasarkan angket kecerdasan logika matematika, didapatkan 3 orang siswa yang memiliki kecerdasan logika matematika dengan kategori tinggi, sedang dan rendah. Pemaparan berpikir literasi matematika siswa dengan kecerdasan logika matematika tinggi, sedang dan rendah adalah sebagai berikut:

1. Siswa 1 (kecerdasan logika matematika kategori tinggi)

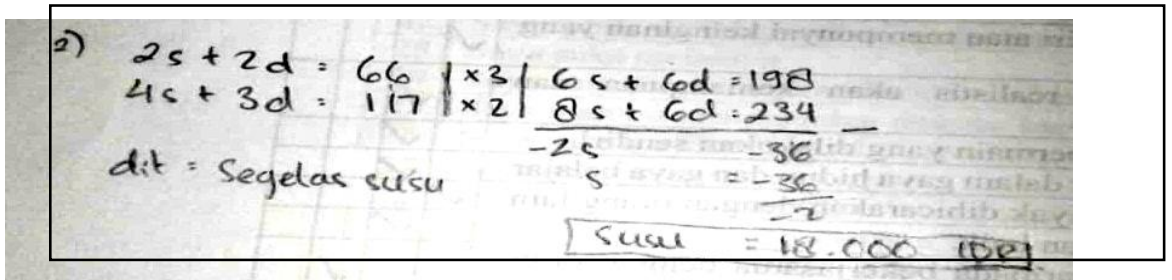

\section{Gambar 2 Jawaban Siswa dengan Kecerdasan Logika Matematika Kategori Tinggi}

Berikut deskripsi kemampuan berpikir literasi matematika siswa dengan kecerdasan logika matematika kategori tinggi berdasarkan indikator kemampuan berpikir literasi matematika, yang terdiri dari tiga komponen yaitu (1) merumuskan situasi secara matematis; (2) menerapkan konsep matematika, fakta, prosedur dan penalaran matematika; dan (3) menafsirkan, menerapkan dan mengevaluasi hasil matematika.

a. Berdasarkan jawaban siswa (Gambar 2), siswa mampu mengidentifikasi konsep SPLDV karena siswa menuliskan model matematika dari soal dengan menggunakan konsep SPLDV, selain itu siswa juga menuliskan apa yang ditanyakan dari soal. Selanjutnya, siswa mampu menggambarkan situasi matematis atau membuat model matematika dari soal, hal tersebut terlihat dari sebelum siswa melakukan proses eliminasi, siswa terlebih dahulu menggambarkan situasi matematis dari soal yang diberikan. Serta pada indikator menemukan hubungan antar variabel, siswa mampu menemukannya, terlihat dari proses eliminasi untuk menemukan jawaban. Selanjutnya, dalam membuat model matematika, siswa mampu melakukannya, 
terlihat dari pemodelan matematika saat melakukan langkah eliminasi.

b. Berdasarkan jawaban siswa, pada komponen berpikir literasi yang kedua, siswa memenuhi ketiga indikator. Karena siswa dapat merancang strategi untuk menemukan konsep SLPDV, selanjutnya menerapkan rumus atau pemodelan matematika dari soal yang diberikan, serta siswa mampu melakukan operasi dan struktur saat menemukan solusi dari permasalahan yang diberikan, siswa pun mampu menemukan pola SPLDV, dan siswa mampu mengolah data dan informasi yang terdapat dalam soal untuk memecahkan masalah.

c. Berdasarkan jawaban siswa, pada komponen berpikir literasi ketiga, siswa mampu menginterpretasikan hasil pemecahan masalah ke dalam konteks nyata dan siswa menyimpulkan pemecahan masalah yang didapatkan.

2. Siswa II (kecerdasan logika matematika kategori sedang)

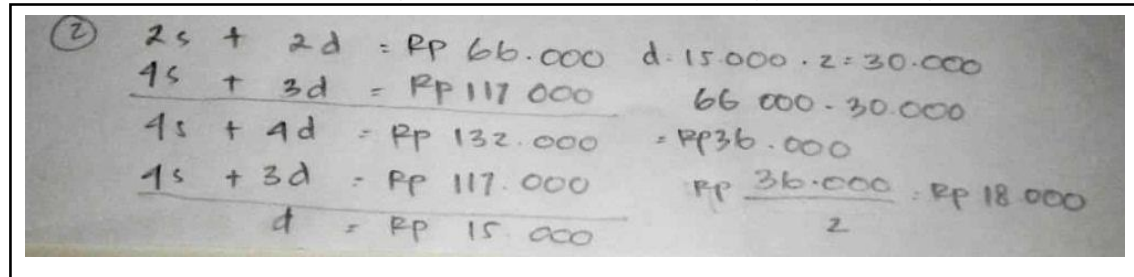

Gambar 3 Jawaban Siswa dengan Kecerdasan Logika Matematika Kategori Sedang

Berikut deskripsi kemampuan berpikir literasi matematika siswa dengan kecerdasan logika matematika kategori sedang berdasarkan indikator kemampuan berpikir literasi matematika, yang terdiri dari tiga komponen diantaranya: (1) merumuskan situasi secara matematis; (2) menerapkan konsep matematika, fakta, prosedur dan penalaran matematika; dan (3) menafsirkan, menerapkan dan mengevaluasi hasil matematika.

a. Berdasarkan jawaban siswa (Gambar 3), bahwa pada komponen berpikir literasi matematika yang pertama, siswa menuliskan informasi dari soal dengan menuliskan apa yang 
ditanyakan dari soal, serta siswa mampu menemukan hubungan antar variabel, dan siswa membuat model matematika berdasarkan permasalahan, hal tersebut terlihat dari pemodelan matematika saat siswa melakukan proses eliminasi untuk menemukan solusi dari soal.

b. Siswa pada komponen berpikir literasi kedua, mampu merancang strategi dalam menemukan pola untuk penyelesaian masalah, menerapkan fakta, melakukan operasi dan struktur untuk menemukan solusi, dapat menemukan pola yang selanjutnya data dan infomasi yang telah disusun diolah untuk memecahkan masalah.

c. Berdasarkan jawaban siswa bahwa pada komponen berpikir literasi ketiga, siswa mampu menginterpretasikan hasil pemecahan masalah ke dalam konteks nyata serta siswa dapat menuliskan kesimpulan yang didapatkan dengan tepat.

3. Siswa III (kecerdasan logika matematika kategori rendah)

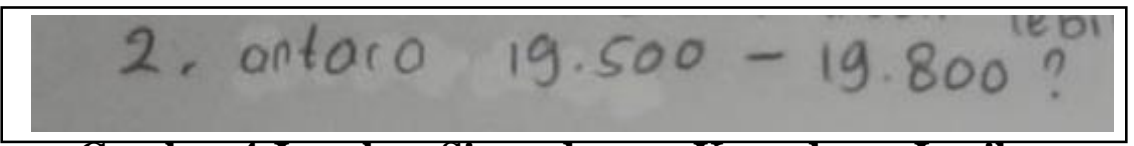

Gambar 4 Jawaban Siswa dengan Kecerdasan Logika

Matematika Kategori Rendah

Berikut deskripsi kemampuan berpikir literasi matematika siswa dengan kecerdasan logika matematika kategori rendah berdasarkan indikator kemampuan berpikir literasi matematika, yang terdiri dari tiga komponen yaitu (1) merumuskan situasi secara matematis; (2) menerapkan konsep matematika, fakta, prosedur dan penalaran matematika; dan (3) menafsirkan, menerapkan dan mengevaluasi hasil matematika.

a. Berdasarkan jawaban siswa (Gambar 4), pada komponen berpikir literasi matematika yang pertama, siswa 3 tidak memenuhi semua indikator, karena siswa tidak dapat mengidentifikasi konsep SPLDV dari soal yang diberikan, terlihat dari jawaban siswa yang tidak menuliskan apa yang diketahui atau ditanyakan dari soal. Serta tidak menggambarkan 
situasi matematis atau menuliskan pemodelan matematika yang bersumber dari soal, siswapun tidak menuliskan hubungan antar variabel serta siswa tidak membuat model matematika dari soal yang diberikan.

b. Berdasarkan jawaban siswa (Gambar 4), pada komponen berpikir literasi yang kedua siswa hanya memenuhi satu indikator, dimana siswa tidak merancang strategi untuk menemukan pola SPLDV, indikator selanjutnya pun tidak terpenuhi, seperti siswa tidak mengaplikasikan informasi dari soal, serta tidak mengoperasikan konsep untuk menemukan solusi dari soal yang diberikan. Tetapi siswa menemukan pola, mengolah data dan informasi yang didapatkan dari soal walaupun hasil yang dituliskan belum tepat.

c. Berdasarkan jawaban siswa (gambar 4) pada komponen berpikir literasi ini, siswa tidak memenuhi semua indikator. Karena siswa tidak menginterpretasikan kembali hasil, hasil atau jawaban siswa masih kurang tepat, dan siswa pun tidak menuliskan kesimpulan dari jawaban yang diberikan terhadap tes kemampuan literasi matematika yang diberikan.

Berdasarkan pemaparan di atas, berikut perbedaan siswa dengan kecerdasan logika matematika kategori tinggi, sedang dan rendah berdasarkan indikator kemampuan berpikir literasi matematika.

\section{Tabel 3 Perbedaan Berpikir Literasi Matematika Siswa dengan Kecerdasan Logika Matematika Kategori Tinggi, Sedang dan Rendah}

\begin{tabular}{|c|c|c|c|c|}
\hline \multirow[t]{2}{*}{$\begin{array}{c}\text { Komponen Proses Berpikir } \\
\text { Literasi Matematika }\end{array}$} & \multirow[t]{2}{*}{$\begin{array}{l}\text { Indikator } \\
\mathrm{Ke}\end{array}$} & \multicolumn{3}{|c|}{$\begin{array}{c}\text { Kecerdasan } \\
\text { Logika Matematika }\end{array}$} \\
\hline & & Tinggi & Sedang & Rendah \\
\hline \multirow{4}{*}{$\begin{array}{l}\text { Merumuskan } \\
\text { matematis }\end{array}$} & 1 & $\checkmark$ & - & - \\
\hline & 2 & $\checkmark$ & $\checkmark$ & - \\
\hline & 3 & $\checkmark$ & $\checkmark$ & - \\
\hline & 4 & $\checkmark$ & $\checkmark$ & - \\
\hline \multirow{3}{*}{$\begin{array}{l}\text { Menerapkan } \\
\text { matematika, fakta, prosedur } \\
\text { dan penalaran matematika }\end{array}$} & 1 & $\checkmark$ & $\checkmark$ & - \\
\hline & 2 & $\checkmark$ & $\checkmark$ & - \\
\hline & 3 & $\checkmark$ & $\checkmark$ & $\checkmark$ \\
\hline
\end{tabular}




\section{Menafsirkan, menerapkan dan mengevaluasi hasil matematika

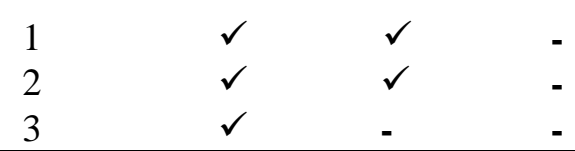

Indikator yang digunakan pada tabel tersebut merupakan indikator berpikir literasi yang terdapat pada Tabel 2 .

Berdasarkan tabel tersebut, terlihat bahwa siswa dengan kecerdasan logika matematika kategori tinggi memenuhi semua indikator pada ketiga komponen berpikir literasi matematika, siswa dengan kecerdasan logika matematika kategori sedang hanya beberapa indikator yang terpenuhi dan siswa dengan kecerdasan logika matematika kategori rendah tidak memenuhi semua indikator dari ketiga komponen berpikir literasi matematika.

\section{Pembahasan}

Siswa dengan kecerdasan logika matematika kategori tinggi, memenuhi ketiga komponen berpikir literasi matematika. Hal tersebut tidak jauh beda dengan hasil penelitian yang dilakukan oleh Fakhriana dkk (2018) bahwa siswa yang memiliki kecerdasan logika matematika kategori tinggi dapat menetukan dan memahami permsalahan yang diberikan, dapat mengidentifikasi dan memilih informasi relevan, dapat membuat model matematika dan mampu memberikan argumen di setiap langkah pemecahan dan simpulan yang ditariknya.

Siswa dengan kecerdasan logika matematika kategori sedang memenuhi beberapa komponen dari ketiga komponen berpikir literasi, karena siswa tidak melakukan beberapa indikator, yaitu siswa belum mengidentifikasi konsep dan mengevaluasi kembali hasil jawaban. Ketercapaian siswa dengan kecerdasan logika matematika kategori sedang pada indikator berpikir literasi matematika, sejalan dengan hasil penelitian yang dilakukan oleh Fakhriana dkk (2018) bahwa siswa yang memiliki kecerdasan logika matematika kategori sedang dapat menentukan dan memahami permasalahan yang diberikan, dapat membuat model matematika dari informasi yang tersedia dalam soal serta mampu menarik kesimpulan. 
Sedangkan siswa dengan kecerdasan logika matematika kategori rendah hanya dapat menuliskan pola, mengolah data dan informasi dari soal yang belum tepat. Hal tersebut tidak jauh beda dengan hasil penelitian yang dilakukan oleh Fakhriana dkk (2018) bahwa siswa yang memiliki kecerdasan logika matematika kategori rendah belum dapat mengidentifikasi dan memilih informasi yang relevan, belum memiliki pandangan untuk mengaitkan permasalahan dan informasi yang didapatkan dengan pengetahuan lain untuk dimanfaatkan dalam proses peemcahan masalah serta kesulitan dalam memberikan kesimpulan dengan tepat.

\section{SIMPULAN}

Kesimpulan yang didapatkan dari pemaparan kemampuan berpikir literasi siswa yang memiliki kecerdasan logika matematika kategori tinggi, sedang dan rendah yaitu siswa yang memiliki kecerdasan matematika kategori tinggi memenuhi indikator dari tiga komponen berpikir literasi matematika, siswa dapat membuat pemodelan matematika dari soal, siswa dapat mengaplikasikan konsep berdasarkan fakta yang terdapat pada soal, serta menerapkan langkah-langkah serta penalaran untuk menyelesaikan soal, selain itu siswa mampu menggambarkan, mengaplikasikan dan memeriksa kembali hasil matematika yang didapatkan dari hasil jawaban siswa terhadap tes kemampuan berpikir literasi matematika.

Siswa yang memiliki kecerdasan logika matematika kategori sedang hampir memenuhi semua indikator dari tiga komponen berpikir literasi matematika. Dimana indikator yang tidak terpenuhi oleh siswa yaitu siswa belum dapat mengidentifikasi konsep dari soal serta belum dapat mengevaluasi hasil jawabannya. Selanjutnya, siswa yang memiliki kecerdasan logika matematika kategori rendah hanya memenuhi satu indikator dari tiga komponen kemampuan literasi matematika yaitu mengolah data dan informasi dari soal, dimana siswa hanya menuliskan hasil, serta hasil yang dituliskan pun belum tepat.

Adapun pada penelitian ini hanya terbatas pada analisis berpikir literasi matematika siswa dengan kecerdasan logika matematika kategori 
tinggi, sedang dan rendah, selain itu siswa yang dijadikan subjek penelitian hanya 3 orang serta pengumpulan data dilakukan dengan dua metode yaitu dengan memberikan angket dan tes. Sehingga berdasarkan keterbatasan-keterbatasan pada penelitian ini, maka disarankan untuk peneliti yang akan mengkaji mengenai berpikir literasi matematika dapat menganalisis siswa dengan kecerdasan majemuk yang lain selain logika matematika. Jumlah subjek penelitian pun dapat lebih banyak supaya terdapat perbandingan antar subjek penelitian. Selanjutnya, untuk pengambilan data dapat dilakukan dengan berbagai cara, agar hasil penelitian dapat lebih baik.

\section{DAFTAR PUSTAKA}

Aini, N. R., Suharto, \& Yudianto, E. (2018). Analisis Berpikir Literasi Matematika Siswa dalam Menyelesaikan Soal Matematika pada Pokok Bahasan Pola Bilangan Berdasarkan Kecerdasan Majemuk. Kadikma, 9(2), 127-135. Retrieved from https://jurnal.unej.ac.id/index.php/kadikma/article/view/9964

Elisa, E. A. (2017). Kemampuan Literasi Matematika Siswa Kelas VIII dalam Menyelesaikan Soal PISA Konten Bilangan Ditinjau dari Kecerdasan Majemuk. MATHEdunesa, 1(6). 67-72. Retrieved from https://jurnalmahasiswa.unesa.ac.id/index.php/mathedunesa/article/v iew/19776

Fadillah, A., \& Ni'mah. (2019). Analisis Literasi Matematika Siswa dalam Memecahkan Soal Matematika PISA Konten Change and Relationship. Jurnal Teori Dan Aplikasi Matematika, 3(2), 127-131. Retrieved from http://journal.ummat.ac.id/index.php/jtam/article/view/1035

Fakhriyana, D., Mardiyana, \& Aryuna, D. R. (2018). Analisis Kemampuan Literasi Matematika dalam Memecahkan Masalah Model Programme For International Student Assessment (PISA) pada Konten Perubahan dan Hubungan Ditinjau dari Kecerdasan Logis Matematis Siswa Kelas IX SMP Muhammadiyah Program Khusus Surakarta. Jurnal Pendidikan Matematika, 11(6), 421-434. Retrieved from https://jurnal.uns.ac.id/JMMS/article/view/37672 
Fathani, A. H. (2016). Pengembangan Literasi Matematika Sekolah dalam Perspektif Multiple Intelligences. Edusains, 4(2), 136-150. https://ejournal.iain-palangkaraya.ac.id/index.php/edusains/article/view/524

Holis, N. M., Kadir, \& Latief, S. (2016). Deskripsi Kemampuan Literasi Matematika Siswa SMP di Kabupaten Konawe. Jurnal Pendidikan Matematika, 4(2), 141-152. Retrieved from http://ojs.uho.ac.id/index.php/JPPM/article/view/3070

Indrawati, F. A., \& Wardono. (2019). Pengaruh Self Efficacy Terhadap Kemampuan Literasi Matematika dan Pembentukan Kemampuan 4C. PRISMA, Prosiding Seminar Nasional Matematika 2 2019, 2, 247-267. Retrieved from https://journal.unnes.ac.id/sju/index.php/prisma/article/view/29307

Kurniawati, I., \& Kurniasari, I. (2019). Literasi Matematika Siswa dalam Menyelesaikan Soal PISA Konten Space and Shape Ditinjau dari Kecerdasan Majemuk. MATHEdunesa, 8(2), 441-448. Retrieved from https://jurnalmahasiswa.unesa.ac.id/index.php/mathedunesa/ article/view/28917

Mhakure, D., \& Mokoena, M. A. (2011). A Comparative Study of the FET Phase Mathematical Literacy and Mathematics Curriculum. USChi na Education, 3, 309-323. Retrieved from https://eric.ed.gov/?q=A+comparative+study+of +the+FET+Phase+ Mathematical+literacy\&id=ED524823

OECD. (2019). PISA 2018 Assesment and Analyttical Framework. Paris: OECD Publishing.

Rahmawati, I., Dara, Y. P. dan Rahma, U. (2019). Pemahaman Konsep Belajar Untuk Mengasah Kecerdasan Majemuk: Pendekatan Penelitian Tindakan. Psycho Idea, 17(1), 42-51. Retrieved from http://jurnalnasional.ump.ac.id/index.php/PSYCHOIDEA/article/vie w/3693/0

Rosalina, A. D. dan Ekawati, R. (2017). Profil Pemecahan Masalah Pada Konten Change and Relationship Siswa SMP Ditinjau Dari Kecerdasan Lingistik, Logis-Matematis, Dan Visual-Spasial, MATHEdunesa. 3(6), 53-62. Retrieved from https://jurnalmahasiswa.unesa.ac.id/index.php/mathedunesa/article/v 
iew/21725

Salafudin. (2015). Pembelajaran Matematika yang Bermuatan Nilai Islam. Jurnal Penelitian, 12(2), 223-243. Retrieved from http://ejournal.iainpekalongan.ac.id/index.php/Penelitian/article/view/651

Syawahid, M., \& Putrawangsa, S. (2017). Kemampuan Literasi Matematika Siswa SMP Ditinjau dari Gaya Belajar. Beta Jurnal Tadris Matematika. 10(2), 222-240. Retrieved from http://jurnalbeta.ac.id/index.php/betaJTM/article/view/121 